き約 1.90 圓となる

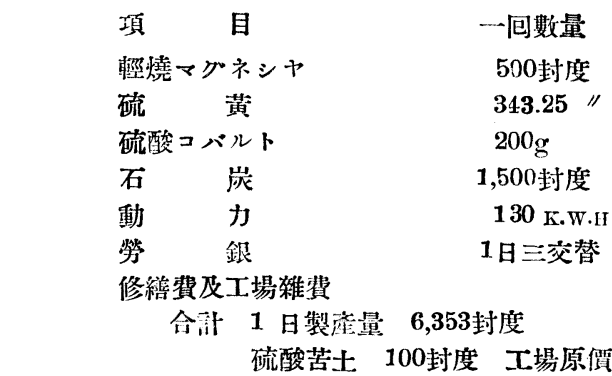

五表

單 貨

1 噸 40滈

1 噸 70[渞]

1 封度 3圆

1 噸 14湏

1 k. W.II. 3 錢

（7）結

論

$$
\begin{gathered}
1 \text { 日(三回) 價格 } \\
26.790 \\
32.180 \\
4.000 \\
28.130 \\
11.700 \\
15.000 \\
2.800 \\
120.600 \\
1.898
\end{gathered}
$$

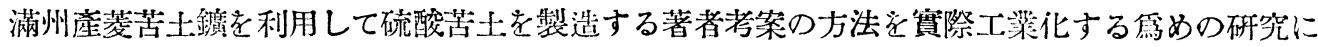
して純粹なる硫酸等士 100 封度を 1.90 圓以队にて製造し得

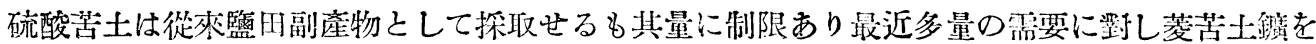
硫酸に溶解する所謂硫酸法起れり該法は硫酸を多量に使用し生童費の過本を占むる硫酸價格によ りて掣肘せらる」事多く向純粹なる製品を得るには技術上至蜼なり然るに著者の方法は簡單に純

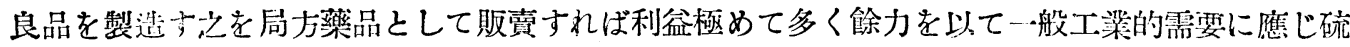

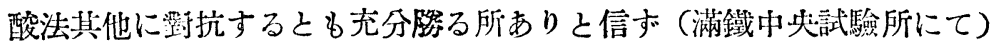

$$
\text { (大正一酹年一月二四日受理) }
$$

\title{
カルシウム・チアナミドの分解に就て(第二報)カルンウ ム・チアナミド溶液と酸州白土との作用に就て \\ 富田英之助
}

著者はカルシウム・チアナミドの分解に就て暴に第一報（本誌嚁和二年第三○編 112 頁)として 土壤中に於けるカルシウム・チアナミドの分解に關する概況を報告したり

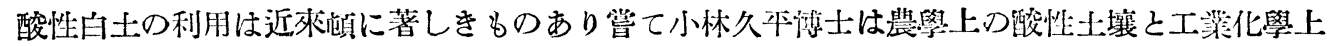
の酸性白土との間には或る種の關係あるものなりよの推論を發表せられたり（本誌大正九年第二 三編 549 頁)著者亦同博士の推諭に首肯する所ありたれば表題の目的に關係してカルシゥム・チア ナミドと酸性白土との作用に就を聊か研究を試みたれば玄に報告せんとす

\section{實驗}

酸性白土は新潟縣靑海越後酸性白土工業所の販賣に係り其の原產地は不明にして赤色のものと 
淡白色のものとの二種なりき實驗には赤色のものを使用したり之它試驗せるに溫度 $105^{\circ} \mathrm{C} に$ 於 ける減量 $12.35 \%$ にしてブンゼン燈焰上に於ける灼熱減量 $4.5 \%$ なりき

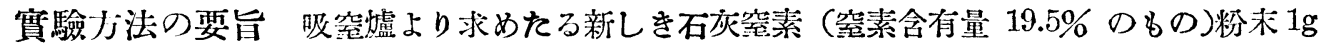
交精䄻して $500 \mathrm{ce} の$ 测定フラスコに入れ蒸溜水 $400 \mathrm{cc}$ を注ぎ 1 時間振蕰したる後標點まで水を 滿たし後乾燥滤紙にて滤過し㵝澄なるカルシウム・チアナミド溶液を得たり而して此の清澄液を

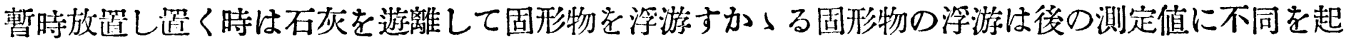

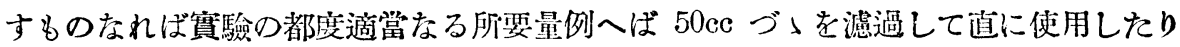

酸性曰土は之れを溫度 $105^{\circ} \mathrm{C}$ に於て充分に乾燥せしめたるものと乾燥工程を加へざる未乾燥 のものとの二種を撰びたり

カルシウム・チアナミドの清澄なる液 $50 \mathrm{cc}$ を採りて酸性白士を $1 \mathrm{~g} .2 \mathrm{~g} .4 \mathrm{~g}$ 正確に椓りて 之れに扣一溫度 $30 、 40 、 50 、 60 、 70 、 80 、 90^{\circ} \mathrm{C}$ の七種に分ち各溫度にて 1 時間保持せしめ此 の 1 時间中 10 分間每に一间約 1 分間振䔽したり 1 時間後乾燥滤紙を用ひて滤別し其の清澄液 に就きチアナミド性空素の量を测定し酸性白土を㧈へざる元の溶液の單位量中のチアナミド性窒 素量とを比较して以て分解に依りて減少せるチアナミド性窒素の割合を計算せり（チアナミド性 管素の測定は本誌大正六年第二○編 234 頁及化學工藝第九然第八號等を參考となせり)

參考の焉めカルシウム・チアナミドす溶液のみを公內に清置したる場合日數の經過に低るチア ナミド性究素の分解に化る減少の有栐をも觀测したり

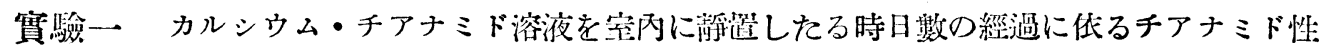
空素の分解減少の你栐壮炏の如し

\begin{tabular}{|c|c|c|c|}
\hline & & - & \\
\hline 加溫々度 & 經過日數 & 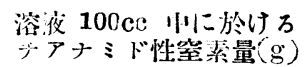 & 分傑減少百分率 \\
\hline 坴內渻度 & 0 & 0.03696 & 0 \\
\hline "I & 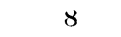 & 0.03491 & 5.46 \\
\hline " & 13 & 0.03472 & 6.05 \\
\hline " & 22 & 0.03080 & 16.66 \\
\hline
\end{tabular}

以下测定山止したり

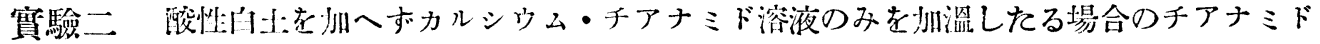
性筑素の分解に依る減少つ有憡を测芫したるに次の如し

第 二 琵

\begin{tabular}{|c|c|c|c|}
\hline 加溫々度 & 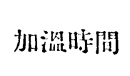 & $\begin{array}{l}\text { 浴液 100cc 怆於ける } \\
\text { チナナミ゙性室素量 }(\mathrm{g})\end{array}$ & 分诤娍少百 \\
\hline $0^{\circ} \mathrm{C}$ & () & 0.03696 & 0 \\
\hline 30 & 1 & 0.03696 & 0 \\
\hline 40 & " & 0.0364 & 1.53 \\
\hline 50 & $"$ & 0.03536 & 4.33 \\
\hline 60 & " & 0.03472 & 6.05 \\
\hline 70 & " & 0.03416 & 7.57 \\
\hline
\end{tabular}




$\begin{array}{llll}80 & \text { " } & 0.03218 & 12.12 \\ 90 & \text { " } & 0.01736 & 52.76\end{array}$

實驗三 カルシウム・チアナミド溶液に乾燥せる酸性白土: $1 \mathrm{~g}$ を加へ加溫處理したる場合に 於けるチアナミド性空素の分解減少の狀況次の如し

第 $\quad \vdots \quad$ 表

\begin{tabular}{|c|c|c|c|}
\hline 加淰 々度 & 加滥時闃 & 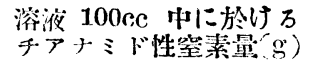 & 分解娍少百分率 \\
\hline $0^{\circ} \mathrm{C}$ & 0 & 0.03472 & 0 \\
\hline 30 & 1 & 0.03472 & 0 \\
\hline 40 & " & 0.03472 & 0 \\
\hline 50 & "1 & 0.03472 & 0 \\
\hline 60 & " & 0.03364 & 3.10 \\
\hline 70 & "I & 0.03304 & 4.66 \\
\hline 80 & " & 0.02856 & 17.68 \\
\hline 90 & "I & 0.02800 & 19.35 \\
\hline
\end{tabular}

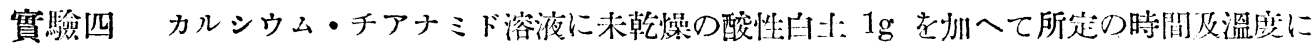
於て處理したるに次の加し

\begin{tabular}{|c|c|c|c|c|}
\hline 加泜々度 & 加㭡時間 & $\begin{array}{l}\text { 溶液 } 100 \mathrm{cc} \text { 中に於けろ } \\
\text { チアナミ゙性窒素量 } \mathrm{g})\end{array}$ & 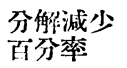 & $\begin{array}{l}\text { 溶液 100cc に對する } \\
\text { 1/10N HCl消費:cc }\end{array}$ \\
\hline $0^{\circ} \mathrm{C}$ & 0 & 0.03472 & o & 31.5 \\
\hline 30 & 1. & 0.03360 & 3.22 & 14..5 \\
\hline 40 & " & 0.0336 ) & 3.22 & 15.6 \\
\hline 50 & " & 0.03360 & 3.22 & 15.6 \\
\hline 60 & " & 0.03248 & 6.45 & 13.0 \\
\hline 70 & " & 0.0308 & 11.29 & 13.0 \\
\hline 80 & "1 & 0.02344 & 32.48 & 11.0 \\
\hline 90 & II & 0.0224 & 35.48 & 8.0 \\
\hline
\end{tabular}

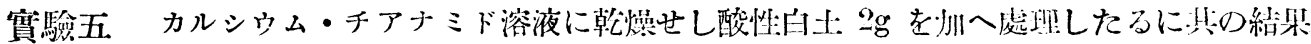
次の如し

\begin{tabular}{|c|c|c|c|c|}
\hline 加溫々度 & 加满時開 & 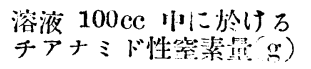 & $\begin{array}{l}\text { 分解減少 } \\
\text { 圢分率 }\end{array}$ & 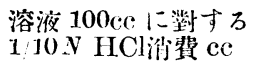 \\
\hline $0^{\circ} \mathrm{C}$ & 0 & 0.03472 & 0 & 3.51 \\
\hline 30 & 1. & $0.0347 \%$ & 0 & 5.0 \\
\hline 40 & "I & 0.03 .172 & 0 & 3.0 \\
\hline 50 & "I & $0.0317 \%$ & 0 & 3.5 \\
\hline 60 & " & 0.03472 & $\mathbf{0}$ & 3.5 \\
\hline 70 & "I & 0.03472 & 0 & 3.5 \\
\hline 80 & " & 0.03136 & 9.67 & 3.5 \\
\hline 90 & " & 0.03024 & 12.90 & 3.0 \\
\hline
\end{tabular}

實驗六 酸性白土未乾燥のもの2g を如へ處理したる結果次の如し

$$
\text { 第 六 表 }
$$

\begin{tabular}{|c|c|c|c|c|}
\hline 加溫々度 & 加溫时間 & 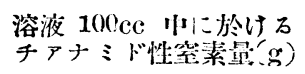 & $\begin{array}{l}\text { 分嶉減少 } \\
\text { 而分萃 }\end{array}$ & 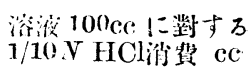 \\
\hline $0^{\circ} \mathrm{C}$ & 0 & 0.03472 & 0 & 39 \\
\hline 30 & 1 & 0.03472 & 0 & 6 \\
\hline
\end{tabular}




\begin{tabular}{|c|c|c|c|c|}
\hline 40 & " & 0.03472 & 0 & 5.0 \\
\hline 50 & " & 0.03304 & 4.83 & 5.5 \\
\hline 60 & " & 0.03304 & 4.83 & 5.0 \\
\hline 70 & "I & 0.03192 & 8.06 & 5.0 \\
\hline 80 & " & 0.03136 & 9.67 & 5.0 \\
\hline 90 & "1 & 0.02288 & 34.10 & 5.0 \\
\hline
\end{tabular}

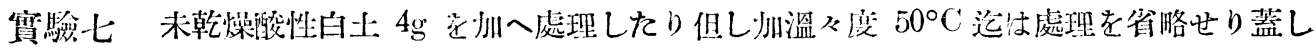

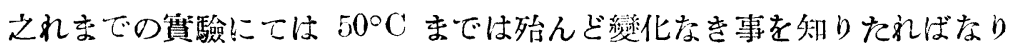

符 七 表

加滔々度
$0^{\circ} \mathrm{C}$
30
50
50
60
70
80
90

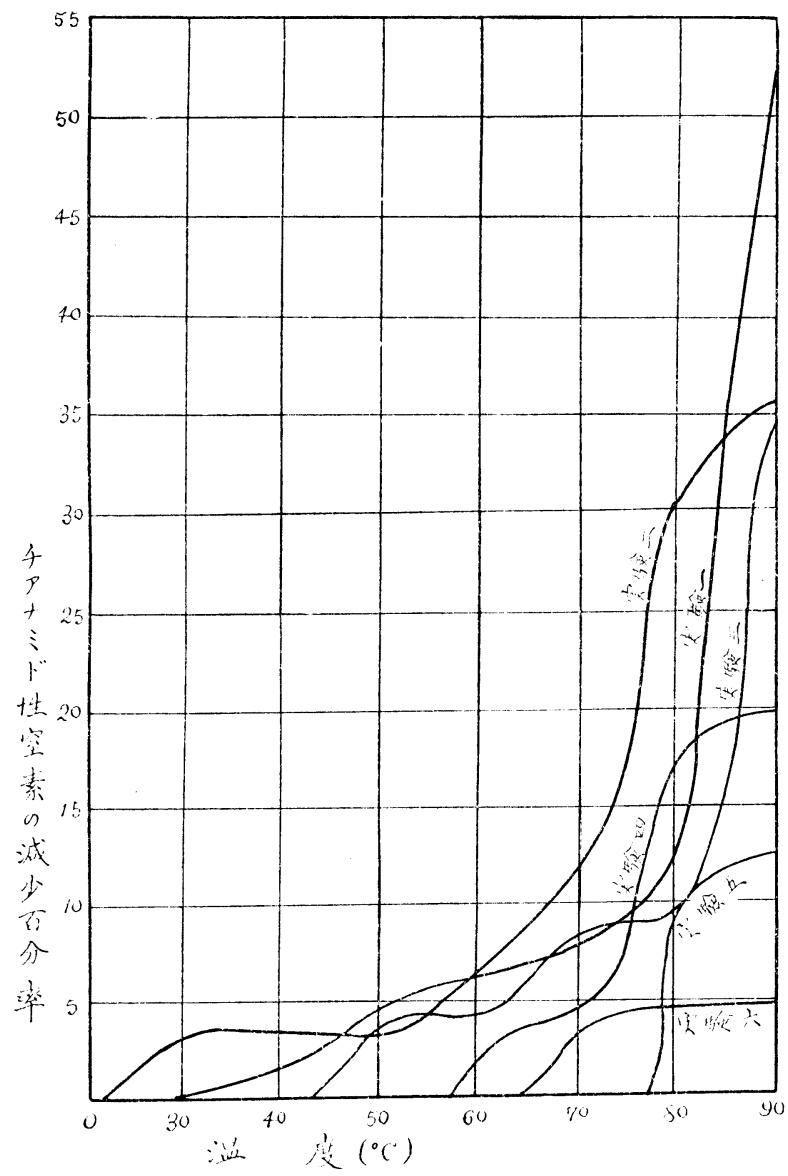

分俳墄少

许分业

淮液 $100 \mathrm{cc}$ はに於ける

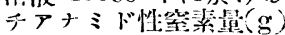
0.03472

0

()

0

0.03472

0.0336

0.03304

$\begin{array}{ll}\text { "/ } & 0.03304 \\ & 0.03304\end{array}$

o

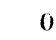

0

()

()

3.22

4.83

4.83

溶液 $100 \mathrm{cc}$ に對する $1 / 10 N$ HCl沙䩀 ce 35.)

0

o

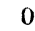

3. 0

3.0

1.0

實驗二〜 の結果を䊉線に依

りて阐示すれば炏の如し

結管位

本研究は何㭱續行中なれ共是れ迄 に得它后處を諭すれば头の如し

（1）酸性白士を扣へボカルシウ ム・チアナミド溶液のみを加溫せし に溫湜の增州に件ひて其の分解は債 加守り例へば溫度 $90^{\circ} \mathrm{C}$ に於て州慍 1 時間にて巳に $50 \%$ 分解与るを見 たり然るに酸性白士を㞦へたるもの は玔へざるものに比し其分解遙に小 なりき

(2) 未乹燥酸性白土，乾燥酸性

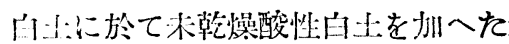
る为の১ガ分解する星大なり

（3）末影燥、乾燥网者を通じて 白士の增州は何れ女分解せらる〉割

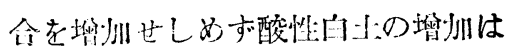


チアナミド性究㙫の分解を大ならしさるものならんさ想定せしが本賽驗に依りて其の然らざるて とを示せり

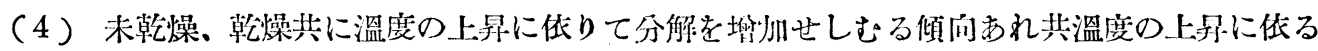

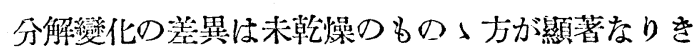

（5）本實驗に用ひたるカルシウム・チアナミド溶液は其の筫カルシウム・チアナミド溶液と 水酸化石灰との混合液なればアルカリ性大なり酸性白土の添师に依りて此のアルカリ度の減少せ られ行くことは實驗に伭りて朋白なりかっる現像は酸性白土の酸性に依るものなるか將又酸性白 土の咇著現象に低るるのなるかは次司に報告せんとす (大正一五年一一月二二日 於大同肥料株式會社）（大正一五年一月三○日受理）

\section{ヴィスコースの研究 (第九報) ヴィスコースに對する 食鹽、硫酸亞鉛、硫酸銅溶液の作用に就采て}

$\begin{array}{lllll}\text { 工學博士 } & \text { 喜 } & \text { 多 } & \text { 源 } & \text { 逸 } \\ \text { 工學士 } & \text { 富 } & \text { 久 } & \text { 松 } \\ \text { 工. 學士 } & \text { 生 } & \text { 叮 } & \text { 䐂 } & \text { 介 } \\ & \text { 藤 } & \text { 本 } & \text { 峰 } & \text { 夫 }\end{array}$

ヴィスコースに食䤉、硫酸亞鉛、硫酸銅溶液を作川せしめたる場合に生成する沈澱の性質につ き行ひなる二、三つ闖騟結果を報告せんとす

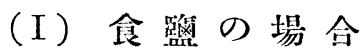

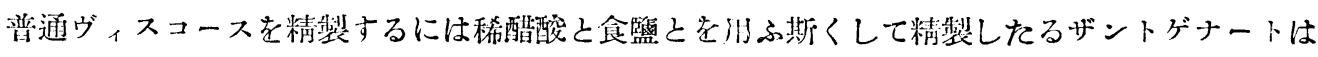
乾燥に當りて如何に變化するか即ち此のザンテートの安定度は如何なる程度なるかを檢したり

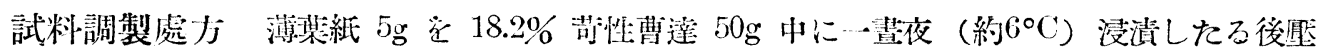

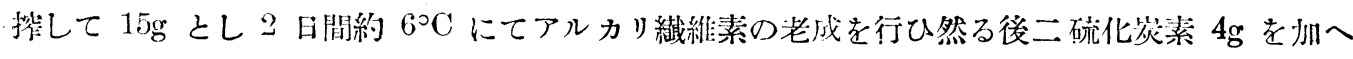

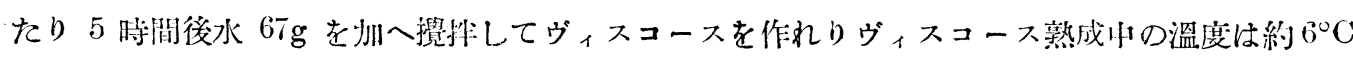
なり

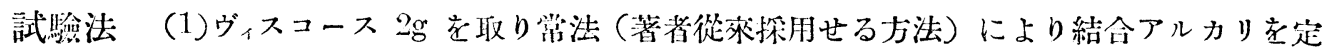
量せり之れをA にて示す

（2）一方ヴィスコース熱成中隔日に $10 \mathrm{~g}$ 宛をとり之れに $1 / 2 N$ 醋酸 $25 \mathrm{ec}$ を加へて揘和し然

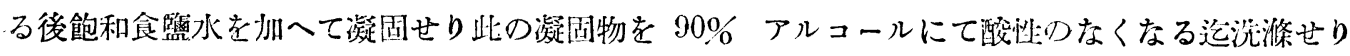

